\title{
Nominal and real wage rigidity: Does nationality matter?
}

\author{
Sónia Cabral* and Cláudia Duarte*
}

*Correspondence:
scabral@bportugal.pt;
cfduarte@bportugal.pt
Banco de Portugal, Economics and
Research Department, Rua
Francisco Ribeiro 2, 1150-165
Lisboa, Portugal

Lisboa, Portugal

\begin{abstract}
We assess the differences in downward nominal and real wage rigidity between natives and immigrants in Portugal, using a matched employer-employee database and the International Wage Flexibility Project (IWFP) methodology. This methodology estimates a notional or counterfactual distribution that would prevail under wage flexibility and compares it to the empirical wage distribution. The estimated measures of wage rigidity capture the share of workers that received a wage freeze but would receive a wage cut in the absence of rigidity. We found that the differences between natives and immigrants are not substantial, but immigrants are more prone to institutional-related rigidities.
\end{abstract}

Keywords: Immigration; Wage rigidity; Matched employer-employee data

JEL Classification: F22; J31; J61

\section{Introduction}

The impact of immigration on the labour market of the host country is an issue much debated for several years and there is an extensive strand of the literature devoted to it. The literature has mostly focused in two different but interrelated broad questions.

First, how do immigrants perform in the host country? It is commonly observed that immigrants earn less upon arrival than comparable native workers but that this wage disadvantage tends to diminish as experience in the host economy increases (Borjas 1999). However, wage assimilation tends to differ across nationalities and, in some countries, the catching up is never complete.

Second, what is the impact of immigration on natives' wages and employment? In a competitive labour market, an increase in the supply of immigrant workers should result in a lower wage or higher unemployment of natives whose skills are substitute and impact positively the natives with complementary skills. However, empirically there is no consensus and, depending on the data and methodology, some studies found a negative and significant effect in native wages (Borjas 2003) but the majority of studies did not obtain a sizeable effect on employment and wages of natives (Ottaviano and Peri 2012).

Assessing the effects of immigration on the labour market of the host country is a complex task. The specificities of immigrant workers in terms of their characteristics and behaviour - lower reservation wages, substitute/complementary skills, higher responsiveness to regional differences in employment opportunities - influence labour market 
efficiency, equilibrium unemployment and wage setting mechanisms. Focusing on the latter, we aim at contributing to the literature by comparing the extent of downward nominal and real wage rigidity for natives and immigrants in Portugal.

With the increasing availability of large employer-employee databases, different approaches have emerged in the literature to estimate aggregate wage rigidities from micro data on individual wages. The International Wage Flexibility Project (IWFP) methodology applied in this paper is one of them. This methodology resulted from the combined effort of a large network studying wage rigidities from individual data of 16 OECD countries, so it has a strong potential of cross-country comparisons. After extensive testing of the different microeconomic approaches existing in the literature, the IWFP methodology was developed to simultaneously estimate the extent of nominal and real wage rigidity and account for measurement error. Evidence of rigidity is obtained by comparing the empirical distribution of wage changes to an estimated notional or counterfactual wage change distribution that would prevail in the absence of rigidity. The estimated measures of nominal and real wage rigidity capture the proportion of workers that received a (nominal or real) wage freeze but would have received a (nominal or real) wage cut under wage flexibility.

As far as we know, this is the first attempt to use this microeconomic approach on wage rigidity differentiating workers by nationality. We did not find substantial differences between natives and immigrants in terms of wage rigidity, but the estimated measures tend to be higher for immigrants, in particular for real wage rigidity. This is associated with the impact of institutional-related rigidity given the higher proportion of immigrants earning the minimum wage.

The article is organised as follows. Section 2 discusses the potential differences between natives and immigrants in terms of wage rigidity. Section 3 presents the longitudinal database used and describes the main characteristics of immigrants relative to those of native workers. The IWFP methodology used in the estimation of wage rigidity is outlined in Section 4. Section 5 presents the empirical results, accounting for the heterogeneity of immigrants by main origins. Finally, Section 6 presents some concluding remarks.

\section{Motivation}

Nominal and real wage rigidity is associated with labour market frictions that prevent the normal adjustment of wages to labour demand, limiting firms' ability to accommodate disturbances in the demand for their products. As opposed to wage flexibility, a rigid wage framework may lead to an adjustment that generates unemployment. The articles in a special feature of The Economic Journal (see (Goette et al. 2007) for a summary) estimate the incidence of nominal and real wage rigidity using a common methodology and workerlevel data for Germany, Italy and the UK and find evidence that downward wage rigidities are associated with unfavourable labour market outcomes, in particular unemployment. If downward wage rigidity is lower for immigrant workers, then immigration would contribute to grease the wheels of the labour market. On the contrary, higher downward wage rigidity for immigrants could amplify the cyclicality of immigrant unemployment, which is typically higher than for natives (Dustmann et al. 2010). But should wage rigidity differ between native and immigrant workers?

The predictions of labour market theories do not all point in the same direction regarding the degree of rigidity for natives and immigrants (see (Campbell and Kamlani 1997) 
for a discussion of the alternative theories on wage rigidity). According to the insideroutsider theory (Lindbeck and Snower 1988), insiders have more power to influence the wage-setting process and tend to have higher wage rigidity. As native workers tend to have more bargaining power, this suggests that they could have more rigid wages. Furthermore, in Portugal the share of immigrants with permanent contracts is much smaller than the share of natives. So, the contract theory (Taylor 1979) also suggests that native workers would have higher wage rigidity. The adverse selection model applied to quits predicts that the most productive workers are most likely to quit after a wage cut. So, firms would be less likely to cut wages of the more-skilled and/or more-tenured workers. In addition, firms are more willing to retain workers with more firm-specific human capital which also implies a higher rigidity of wages of workers with higher tenure. Given the recent nature of most immigrant flows in Portugal, these theories suggest a higher wage rigidity for natives.

In contrast, as discussed in (Du Caju et al. 2007), the cost of losing a job is higher for older workers and workers with higher tenure. These workers have, therefore, less incentive to shirk or quit, even in presence of wage cuts, implying a higher likelihood of a wage cut for them and, thus, lower wage rigidity. The opposite applies to immigrants, which are, on average, younger and have lower tenures.

Institutional factors can also play a role on the degree of rigidity for natives and immigrants. As immigrant workers in Portugal tend to be at the bottom of the wage distribution, their wages are more likely to be (fully) determined by the legal lower boundaries to wages (national minimum wage and wage floors of sectoral agreements) and, thus, will be more rigid. Overall, assessing whether wage rigidity is higher for immigrant or native workers is ultimately an empirical question.

\section{Database and exploratory analysis}

The database used is Quadros de Pessoal (QP), a longitudinal dataset matching workers and firms based in Portugal. This administrative data draws on an annual mandatory employment survey that covers virtually all firms with wage earners in a reference month (October), excluding public administration and domestic work. Besides the advantage of its comprehensive coverage, it is also generally recognised that this dataset is reliable by virtue of its public availability.

Reported data include several characteristics of firms (e.g. identifier, location, employment) and workers (e.g. identifier, education, type of contract, hours worked, earnings). Some filters were imposed on the database to eliminate erroneous, inconsistent or missing reports. First, the analysis was restricted to individuals for whom there was information available for a set of key variables, such as gender, age, nationality and sector of activity. Second, we further restricted our sample to workers aged between 15 and 80 years and with a job tenure below 65 years. Third, we focused our analysis on the full-time employees segment and we only considered those employees that reported a base wage of at least 80 percent of the minimum legal wage ${ }^{1}$. Fourth, we used a regular wage measure that includes the base wage (monthly gross pay for normal hours of work) and the regular subsidies and premiums paid on a monthly basis, like seniority payments.

The worker-level data cover all years since 1986, except 1990 and 2001, but information on the nationality of the worker only starts in 2000 , so our sample period starts in 2002 and ends in 2008 . The exact nationality at the country level is the only information 
available to identify immigrant workers in QP, as neither the place of birth nor the year of arrival in Portugal are recorded. Nevertheless, given the low naturalisation rate, the sample of immigrants covered in the QP database seems to be a good approximation of the target population.

\subsection{Exploratory analysis}

Historically, Portugal has been a country of emigration, but in the late nineties immigration flows grew strongly driven by high labour demand. A significant share of this new immigration flows came from Central and Eastern European countries (CEEC), i.e., from countries with no evident cultural link with Portugal. More recently, there was a very significant increase in immigrants from Brazil. Immigration from China, although growing strongly in the last decade, still represents a small share of total immigrant workers. At present, three major groups make up the bulk of immigration in Portugal, representing around 75 percent of total: Brazil, Portuguese speaking countries in Africa (PALOP) and CEEC.

Full-time employed immigrants increased by 47 percent from 2002 to 2008, representing 6.4 percent of total employment in 2008. Table 1 reports the sample means of some relevant variables for natives and immigrants, as well as for the main nationalities of immigrant workers.

One of the most notable differences between immigrants and natives relates to the type of contract. In the 2002-2008 period, more than half of immigrant workers had a fixedterm contract, compared to around 22 percent for natives. Immigrants from Brazil and CEEC have the highest proportion of fixed-term contracts.

Immigrant workers are younger than natives. Workers with less than 35 years account for around 43 percent of total natives but represent about 50 percent of immigrants. This difference is higher in the case of workers from China and, especially, from Brazil.

Given the recent nature of immigration in Portugal, the average tenure of immigrant workers is much lower than that of natives. Within immigrants, tenure is higher for workers from the EU15 and, to a lesser extent, from PALOP, which are the immigrant groups that have been longer in the country. The proportion of immigrants with tenure less than 1 year is more than double the share of natives in the same situation. Around 44 percent of native workers have tenure up to 3 years, but that proportion increases to almost 80 percent in the case of immigrants. This result is in line with the higher incidence of fixedterm contracts, mostly with a length of 3 years, in immigrant employment. The share of immigrants with tenure up to 3 years is especially high among workers from China, Brazil and CEEC.

The differences in educational attainment between natives and immigrants as a whole are not substantial, even if the share of illiterates is higher for immigrants. However, there are important differences among the main immigrant groups. Immigrants from China stand out by their extremely low educational level, while the educational attainment of immigrants from the EU15 is significantly higher than that of all other nationality groups.

Immigrant employment is concentrated in a few sectors, namely construction and some services activities. Construction is the main sector of immigrant employment in Portugal, accounting for almost 24 percent of the total. The employment share of the services sector as a whole is similar for natives and immigrants but the breakdown within services is 
Table 1 Main characteristics of total native and immigrant workers in Portugal, average 2002-2008

\begin{tabular}{lrrrrrrr}
\hline & Natives & Immigrants & EU15 & PALOP & CEEC & Brazil & China \\
\hline Total, levels in 2008 & $2,324,699$ & 159,539 & 13,294 & 39,305 & 37,638 & 42,266 & 2,670 \\
Share in total, 2008 & 93.6 & 6.4 & 8.3 & 24.6 & 23.6 & 26.5 & 1.7
\end{tabular}

Type of contract (\%)

Permanent contract

Fixed-term contract

$\begin{array}{lllllll}77.6 & 45.2 & 66.3 & 49.6 & 35.4 & 35.9 & 44.0 \\ 22.4 & 54.8 & 33.7 & 50.4 & 64.6 & 64.1 & 56.0\end{array}$

Age

Average years

$\begin{array}{lllllll}37.9 & 35.7 & 36.5 & 36.5 & 36.3 & 33.0 & 34.3 \\ 43.4 & 50.5 & 51.1 & 45.7 & 47.5 & 62.4 & 53.9\end{array}$

Tenure

Average years

$[0,3]$

of which $<1$

$\begin{array}{rrrrrrr}7.5 & 2.5 & 4.1 & 2.8 & 1.6 & 1.5 & 1.4 \\ 43.7 & 78.6 & 61.8 & 74.6 & 86.2 & 88.0 & 89.1 \\ 15.8 & 37.7 & 24.2 & 37.7 & 38.6 & 46.8 & 43.4\end{array}$

Educational attainment (\%)

Illiterate

4 years completed

6 years completed

9 years completed

12 years completed

Main sectors of activity (\%)

Manufacturing industry
Construction
Services, of which:
Wholesale and retail trade
Hotels and restaurants
Business services
Other sectors

28.4
11.4
57.6
20.0
6.2
9.6
2.6

$15.7 \quad 20.6$

$\begin{array}{llll}5.8 & 5.9 & 5.8 & 3.2\end{array}$

Average nominal monthly wage

\begin{tabular}{lrrrrrrr} 
In Euros & 835.8 & 732.7 & 1436.5 & 668.8 & 596.0 & 716.1 & 449.4 \\
\% Minimum wage earners & 8.0 & 12.6 & 6.8 & 8.4 & 13.3 & 16.7 & 57.3 \\
\hline
\end{tabular}

Source: Quadros de Pessoal.
Notes: The shares of main immigrant groups are computed as a percentage of total immigrants. EU15 includes the other 14 initial Member-States of European Union. CEEC (Central and Eastern European countries) includes Slovakia, Poland, Czech Republic, Hungary, Estonia, Slovenia, Latvia, Lithuania, Romania, Russian Federation, Moldova, Ukraine and Serbia. PALOP (Países Africanos de Língua Oficial Portuguesa) refers to the former Portuguese colonies in Africa (Angola, Cape Verde, Guinea Bissau, Mozambique, and São Tomé and Príncipe). Illiterate refers to no formal education or below ISCED 1, 4 years completed (primary education) and 6 years completed (second stage of basic education) are both included in ISCED 1, 9 years completed refers to ISCED 2 (lower secondary education), 12 years completed refers to ISCED 3-4 (upper-secondary) and tertiary refers to ISCED 5-6. ISCED stands for International Standard Classification of Education. The percentage of minimum wage earners was computed considering workers with wages in the interval of $+/-1$ euro centred on the minimum wage.

very different. Immigrants are especially concentrated in three sub-sectors: hotels and restaurants, business services, and wholesale and retail trade.

Regarding wages, the wage setting system in Portugal is common to both native and immigrant workers irrespective of the type of contract (permanent or fixed-term). This framework is mainly determined by three thresholds and there is not an automatic wage indexation mechanism (see (Carneiro et al. 2012) for a detailed description of the Portuguese wage setting system in this period). First, the lower limit is defined, at the 
national level, through the legal mechanism of the minimum wage. Second, nominal base wage cuts in the private sector are forbidden by law. Finally, in the context of wage bargaining, the majority of the lower wage limits for each professional group are defined by sectoral agreements, as firm agreements are the exception. Afterwards, the Ministry of Labour extends the collective agreements to the workers initially not covered, so the distinction between union and non-union membership is largely meaningless in Portugal. Whatever the minimum contractual wage levels set by collective bargaining, firms are free to pay higher wages and they often deviate from that benchmark (Cardoso and Portugal 2005).

Given this institutional background, the distribution of nominal wage levels has a mode in wages equal to, or very close to, the minimum wage (Figure 1). This is true for both total workers and workers who stayed for at least two consecutive years in the same firm (job stayers) $)^{2}$. As workers who enter a given firm in a given year, either natives or immigrants, tend to earn lower wages, the concentration in the bottom-end of the nominal wage distribution is higher for total workers than for job stayers. Furthermore, in both cases, immigrants are more concentrated in lower wages than natives.

Not controlling for any differentiating factors, immigrants in Portugal are, on average, paid below the nominal wages of native workers in the 2002-2008 period. There are also important differences in average nominal wages among immigrants. The average wage of workers from the EU15 is about twice as high as the average immigrant wage and substantially higher than the average native wage. In contrast, Chinese immigrants earn wages significantly lower than the other immigrant groups.

The percentage of minimum wage earners is higher for immigrants than for natives ${ }^{3}$. Around 8 percent of native workers earn the minimum wage, but the average share of minimum wage earners reaches almost 13 percent for immigrants in this period. Immigrants from the EU15 have the lowest share of minimum wage earners, while almost 60 percent of Chinese workers are reported as earning the minimum wage in this period.

After a period where it remained fairly stable, the percentage of minimum wage earners grew for natives and, even more markedly, for immigrants in 2007 and 2008, amidst very strong increases of the legal minimum wage (Figure 2). From 2002 to 2006, the minimum wage grew approximately at the same rate as prices and contractual wages set in collective

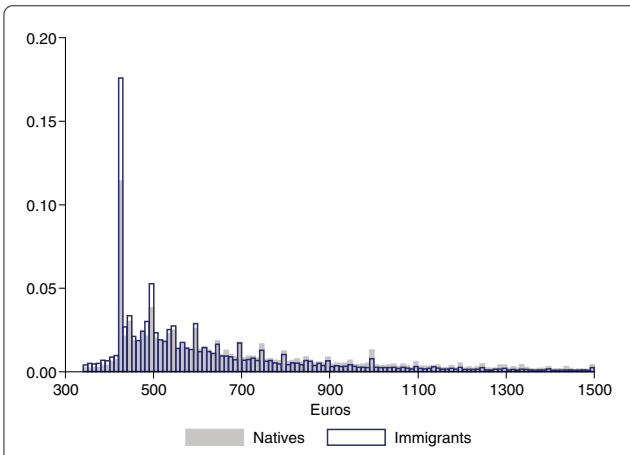

(a)

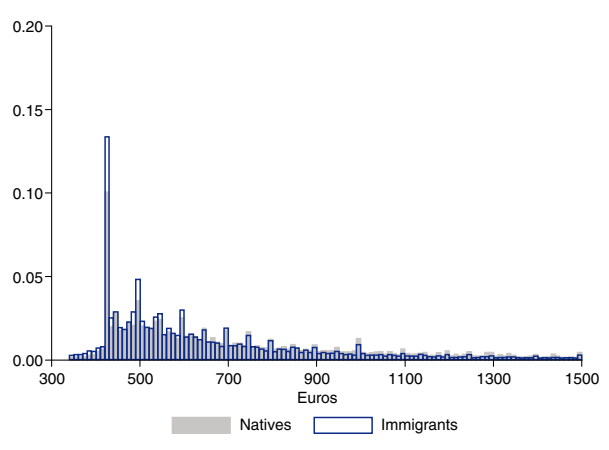

(b)

Figure 1 Distribution of nominal monthly wages levels in Portugal, 2008. (a) Total, (b) Stayers. Source: Quadros de Pessoal.

Note: Job stayers include only workers who stayed for at least two consecutive years in the same firm. 


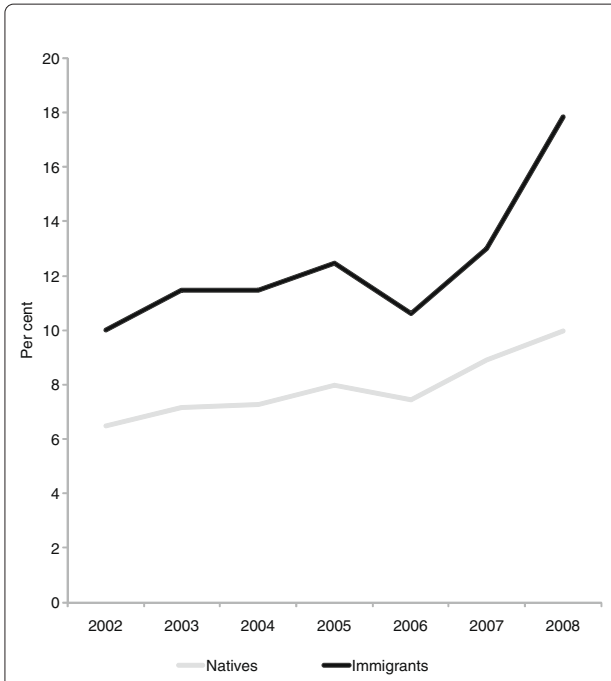

(a)

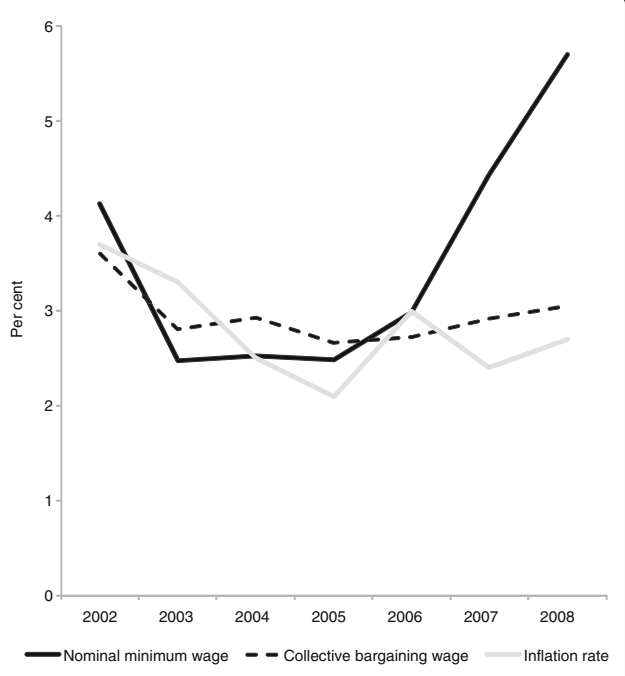

(b)

Figure 2 Nominal minimum wage, 2002-2008. (a) Share of minimum wage earners, (b) Rate of change. Sources: Statistics Portugal and Quadros de Pessoal.

Notes: Workers earning the minimum wage include all workers whose nominal wages lie in an interval of $+/-1$ euros centred on the minimum wage. The observed inflation rate in Portugal is measured by the Harmonised Index of Consumer Prices (HICP).

bargaining, resulting in changes of the real minimum wage close to zero. In 2007 and 2008, the minimum wage increased well above the inflation rate, reflecting the goal of reaching a 500 euros minimum wage by 2011 set in December 2006 (see (Centeno et al. 2011) for a description of the evolution of the minimum wage in Portugal in this period). The nominal minimum wage increased by 4.4 percent in 2007 and 5.7 percent in 2008, which translated into real rates of change of 2.0 and 2.9 percent in 2007 and 2008, respectively ${ }^{4}$.

\section{Methodology and estimation strategy}

Several attempts have been made in order to assess the causes and gauge the consequences of wage rigidity. One strand of the literature relies on estimates of rigidity obtained from macro data (see, for instance, (Akerlof et al. 1996) and (Blanchard and Galí 2007)). Another strand tries to exploit the increased availability of longitudinal databases with extensive information on individual wages.

There are different approaches in the literature to estimate wage rigidities from longitudinal databases. Firstly, studies like those by (Card and Hyslop 1997) and (Dickens et al. 2007) use potential asymmetries in the distribution of wage changes to draw inference about rigidities. This symmetry approach can be problematic when reasonable estimates of the expected rate of inflation lie above the median wage change. Secondly, the histogram-location approach of (Kahn 1997) assumes that the shape of the distribution of wage changes is constant over time in the absence of changes in the extent of rigidity. This non-parametric method depends on the existence of sufficient variation in the median of the distribution, which may not be the case in an environment with relatively low and stable inflation. Thirdly, the earnings-function approach proposed by (Altonji and Devereux 2000) and extended by (Goette et al. 2007) defines the notional wage change that holds under wage flexibility as a function of worker and firm characteristics. Downward wage rigidity and measurement error parameters are jointly estimated 
using maximum likelihood, but the assumption of normality of the distributions of wage changes and measurement errors can be elusive.

The International Wage Flexibility Project (IWFP) was a large network studying wage rigidities from individual data of 16 OECD countries. Using the large database of crosscountry micro data available within the network, these three different microeconomic approaches to estimating wage rigidity were tested (see (Messina et al. 2010)). The results of the various tests, together with the extensive analysis of the data from the several countries, led to the development of a new methodology for jointly estimating the extent of both nominal and real wage rigidity in the presence of measurement error. This methodology for calculating aggregate nominal and real wage rigidity is based on the analysis of the distributions of individual wage changes, requiring a large longitudinal data set but not detailed information on workers and firm characteristics.

According to the IWFP methodology, the nominal rigidity concept is associated with the share of workers who have nil wage changes and would see their wages fall in the absence of rigidity. In turn, real rigidity reflects the share of workers whose wage change is bounded by the expected inflation rate, but would be lower in the absence of rigidity. Estimations of downward nominal and real wage rigidity following the IWFP methodology include the works of (Du Caju et al. 2007), (Duarte 2008) and (Messina et al. 2010).

A detailed review of the IWFP methodology can be found in (Dickens and Goette 2005), so here we will just provide a brief description of it. The theoretical model underlying this methodology assumes that the actual nominal wage change of worker $i$ in period $t$ $\left(d_{i t}\right)$ equals the notional (counterfactual or rigidity-free) nominal wage change $\left(d_{i t}^{n}\right)$ except when rigidity-related constraints exist. So, theoretical nominal wage changes in a rigidityprone labour market are represented by:

$$
d_{i t}= \begin{cases}0, & \text { if }\left(d_{i t}^{n} \leq 0 \text { and } \varepsilon_{i t}^{n}<n_{t}\right) \text { or }\left(-0.01 \leq d_{i t}^{n} \leq 0.01 \text { and } \varepsilon_{i t}^{1}<s_{1 t}\right) \\ & \text { or }\left(-0.02 \leq d_{i t}^{n}<-0.01 \text { or } 0.01<d_{i t}^{n} \leq 0.02 \text { and } \varepsilon_{i t}^{2}<s_{2 t}\right) \\ \pi_{i t}^{e}, & \text { if } d_{i t}^{n} \leq \pi_{i t}^{e} \text { and } \varepsilon_{i t}^{r}<\rho_{t} \\ d_{i t}^{n}, & \text { otherwise }\end{cases}
$$

where $\varepsilon_{i t}^{n}, \varepsilon_{i t}^{r}, \varepsilon_{i t}^{1}$ and $\varepsilon_{i t}^{2}$ are i.i.d. random variables drawn from a uniform distribution on the unit interval, $s_{1 t}$ and $s_{2 t}$ represent the probability of being subject to symmetric nominal rigidity due to the proximity with nil wage change (affected by menu costs), $\pi_{i t}^{e}$ is a normally distributed random variable with mean $\mu_{t}^{\pi^{e}}$ and variance $\sigma_{t}^{\pi^{e}}$ representing the expected rate of inflation for this wage, $n_{t}$ denotes the probability of being subject to downward nominal wage rigidity if the notional nominal wage change is negative and, finally, $\rho_{t}$ the probability of being subject to downward real wage rigidity if the notional nominal wage is less than the expected rate of inflation.

The notional distribution of wage changes is assumed to follow a symmetric Weibull distribution with three parameters - $a_{t}$ denotes the scale parameter, $\mu_{t}$ is the mean of the distribution and $c_{t}$ represents the shape parameter ${ }^{5}$. The expected rate of inflation $\left(\pi_{i t}^{e}\right)$ is assumed to evolve within boundaries. How are these boundaries defined? For a given year, consider the observed inflation rate, its lagged value and an estimate obtained from a simple regression of observed inflation on its first lag. The range for the expected inflation parameter has the minimum of these three figures as the lower bound and the upper bound is their maximum. 
Given this model, the nine parameters of interest - $a_{t}, \mu_{t}, c_{t}, \mu_{t}^{\pi^{e}}, \sigma_{t}^{\pi^{e}}, n_{t}, \rho_{t}, s_{1 t}$ and $s_{2 t}$ - are obtained through an optimisation procedure by the generalised method of moments (GMM), which tries to minimise the squared differences between the theoretical and the observed wage changes. The higher the concentration in the nil wage change of the observed distribution vis-à-vis the notional distribution, the greater the evidence in favour of nominal rigidity and, hence, the higher the measure of nominal rigidity. Similarly, the higher the concentration of the observed distribution, compared with the notional distribution, in a wage change close to the expected inflation rate, the greater the evidence in favour of real rigidity and the higher the value of the measure.

If measurement errors are detected, the procedure for calculating the rigidity measures tries to purge them from the wage change distribution by computing a new distribution, named as the "true" or "error-corrected" distribution, which replaces the observed distribution in Equation 1. The detection of measurement errors is based on the analysis of the autocorrelation of wage changes: positive changes followed by negative changes are taken as a sign of the existence of measurement errors (for further details, see (Dickens and Goette 2005)).

The estimated real rigidity bound $\left(\pi_{i t}^{e}\right)$ does not have a straightforward interpretation, even if the IWFP methodology named it "expected inflation rate" and its range is linked to past and present values of the inflation rate. It can also reflect collective bargaining wage agreements, legal minimum wages and automatic indexation clauses. If institutional rigidities play a significant role in the wage-setting process, distinguishing the different types of rigidity - nominal, real and institutional - becomes extremely difficult. If the reference values for collective bargain and/or minimum wages are similar to the expected inflation rate, the IWFP real rigidity measure will reflect both "strictly" real and institutional rigidities. This fact can be especially relevant in a country like Portugal, that besides having a restrictive job protection legislation for permanent contracts, has a high degree of centralisation in collective bargaining with widespread extension mechanisms and national mandatory minimum wages.

The difficulty to distinguish between"strictly" real and institutional wage rigidities is also evident in the way the average wage sweep-ups are computed with the IWFP methodology. The total average wage sweep-up is simply the difference between the average observed (or "true") wage change and the average notional wage change and can be interpreted as the overall increase in the average wage growth due to the presence of rigidities. In each year, the wage sweep-up from nominal wage rigidity measures the increase in the average wage change because of prevented nominal wage reductions. Instead of decreasing, the wages of workers affected by nominal wage rigidity are frozen. Thus, the impact of downward nominal wage rigidity reflects the difference between a nil wage change and the average notional wage change of the rigidity-affected workers times the percentage of these workers (the estimated $n_{t}$ ). In the IWFP methodology, the wage sweep-up from real rigidity is obtained as a residual given the total average effect of rigidity and the estimated wage effect associated with nominal wage rigidity. This difference measures by how much the average wage change is higher because of the existence of both "strictly" real and institutional rigidities.

The observable individual heterogeneity of wage changes is crucial to the optimisation processes generating both the notional and, if need be, the "true" wage change distributions. However, we can only recover the incidence of wage rigidity at the aggregate level, 
not at the worker-level. For each cross-section of individual wage changes, we obtain a set of parameters which describe the key features of the model: the average rate of notional wage change and its standard deviation, the expected average inflation rate and its standard deviation, the downward nominal and real rigidity measures and the corresponding wage sweep-ups. Given that we do not have the individual probabilities of nominal and real wage rigidity, we cannot regress these probabilities on a set of standard worker and firm-level controls (like union coverage, minimum wage earners, type of contract, sector of activity) and an immigrant dummy identifier. So, our goal of assessing the differences between immigrants and natives in terms of wage rigidity was accomplished by calculating the aggregate measures using separate samples for natives and immigrants ${ }^{6}$.

Using separate samples for natives and immigrants implies that all relevant parameters of the model can independently vary between natives and immigrants. But should the empirical and notional distributions of wage changes be group-specific? Immigrants tend to receive lower wages upon arrival in the host country than comparable native workers. The imperfect portability of human capital acquired in the origin country, as well as the lack of fluency in the destination language, were found to be important determinants of this wage gap (see, for instance, (Friedberg 2000) and (Aydemir and Skuterud 2005)). Over time, immigrants' wages tend to converge as they engage in a process of acquiring skills relevant for the destination country, but, in some countries, the wage gap never closes. For Portugal, (Cabral and Duarte 2013) find major differences in the wage patterns between natives and immigrants and among different immigrant groups. In particular, returns on education and experience differ significantly by nationality in the Portuguese labour market. In this sense, we interpreted that allowing the distributions of wage changes to differ among nationality groups is a positive feature of the IWFP methodology in our case.

\section{Empirical results}

As the IWFP methodology focuses on wage changes that are not influenced by worker mobility, the database was restricted to include only the individuals who worked for at least two consecutive years in the same firm (job stayers). This leads to a substantial reduction of the total number of workers. However, the main differentiating characteristics of natives and immigrants described in Section 3.1 remain valid (see Appendix). In the case of the total and natives samples, the number of job stayers is still very large, so, for computational convenience, a 10 percent random sample was selected for calculating the rigidity measures ${ }^{7}$. In the case of immigrants, the sizes of the samples of job stayers are much smaller. Thus, we used these samples directly in the estimation of the wage rigidity measures.

As expected, the incidence of measurement errors in the QP database is extremely limited and, hence, the differences between the observed distributions of wage changes and the "error-corrected" distributions are virtually nil. We opted to use the observed distributions, but this choice has no significant impact in the results ${ }^{8}$.

All estimates of nominal and real wage rigidity were done using a regular wage measure, which includes the base wage and all regular benefits. For the estimation of wage rigidity from the firm's perspective, a more comprehensive analysis would focus on total labour costs per worker, that is, total compensation, which comprises also all non-regular benefits and overtime pay. However, given that we only have data for one month in each year, to use total compensation could result in spurious wage changes, reflecting the payment 
of non-regular benefits in different months from one year to the other. Another possibility would be to use only the base wage. As a robustness check, we replicated all estimations using the base wage and the main results are qualitatively similar ${ }^{9}$.

Figure 3 displays the histograms of the observed wage change distributions, i.e., the empirical distributions, and the notional rigidity-free distributions of wage changes for the total sample from 2003 to 2008. Contrasting with the notional wage distributions, negative nominal wage changes are very limited in the empirical distributions and there is very high concentration on the zero change. Between 2003 and 2006, the distribution of nominal wage changes has a second mode near the expected inflation rate (and bargaining and minimum wage reference values). In 2007 and 2008, the distribution of wage changes has three spikes - at zero, at the expected inflation rate value (and bargaining reference value) and at the rate of change of the minimum wage. Despite differences in the relative size of the spikes, the main features of the empirical distributions of nominal wage changes - near absence of negative changes and two- or three-spike distributions are common to native and immigrant workers ${ }^{10}$. The fact that the empirical distributions of wage changes show only a small fraction of negative nominal changes and a very high concentration on the nil change suggests resistance to nominal wage declines (nominal rigidity). Furthermore, the existence of a second mode near the expected inflation rate and a smaller concentration in rates immediately below are evidence in favour of real wage rigidity.

The hints obtained from the visual inspection of the wage change distributions are confirmed by the estimated measures of nominal and real wage rigidity displayed in Figure 4 . The Appendix includes the yearly estimates of the notional and empirical average wage changes, the corresponding average wage sweep-ups, the expected inflation rate or real rigidity bound, and the nominal and real rigidity measures for the whole sample and for the separate samples for natives and immigrants. The IWFP methodology accounts for changes in the estimated moments of the notional distributions of wage changes over

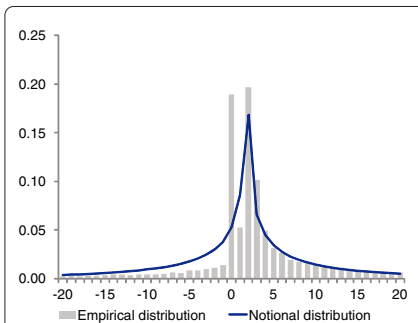

(a)

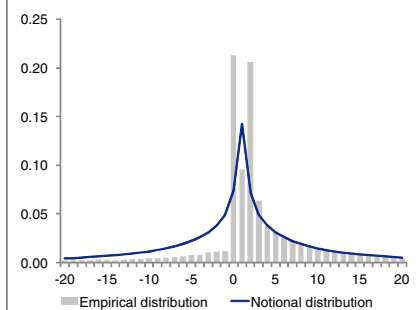

(d)

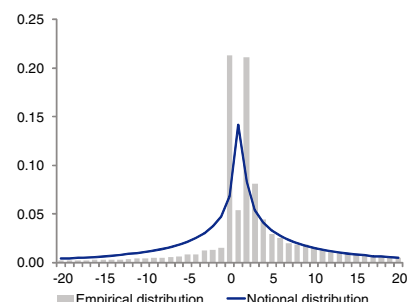

(b)

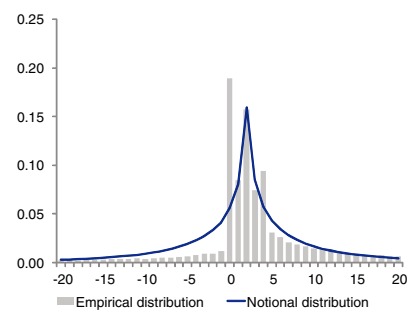

(e)

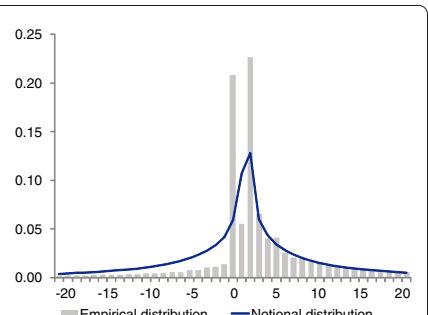

(c)

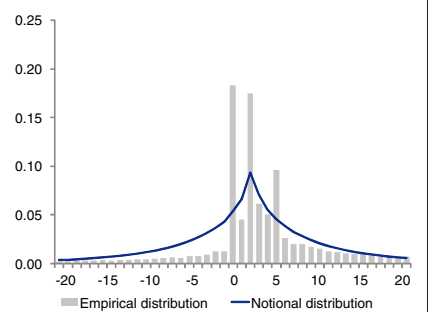

(f)

Figure 3 Distributions of nominal monthly wage changes in Portugal, total sample. (a) 2003, (b) 2004, (c) 2005, (d) 2006, (e) 2007 and (f) 2008. 


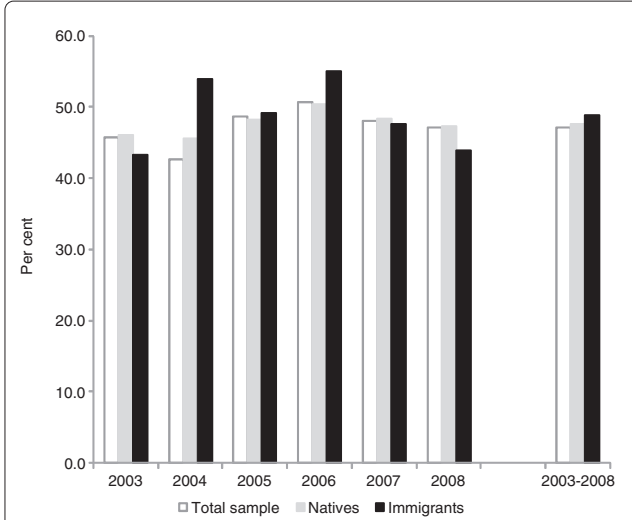

(a)

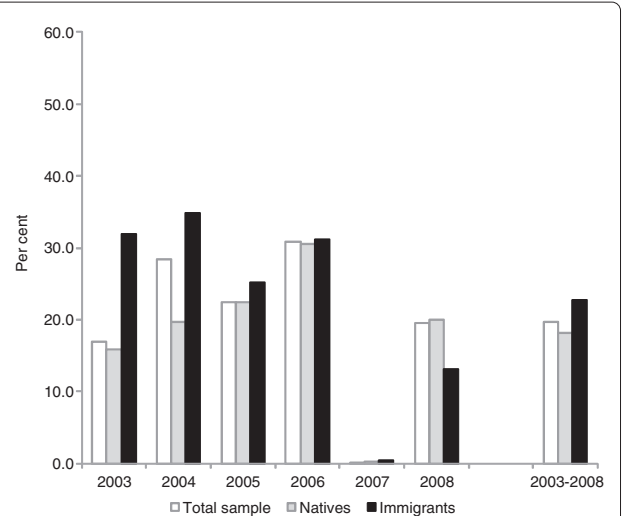

(b)

Figure 4 Nominal and real wage rigidity for natives and immigrants in Portugal. (a) Downward nominal wage rigidity, (b) Downward real wage rigidity.

years and samples, as well as for changes in the focal points for the computation of real wage rigidity. Therefore, separate estimates for different sub-samples (natives and immigrants, in this case) do not necessarily average out to the estimate for the entire sample.

Let us now examine in more detail the percentage of workers affected by nominal and real wage rigidities. For the total sample, 47.1 percent of the workers who would have a nominal wage cut in the absence of rigidity, have instead nil wage changes in the period 2003-2008. This result not only is influenced by the legal framework associated with the existing barriers to nominal base wage cuts, but is also related to the fact that, even in the absence of legal constraints, firms tend to avoid nominal wage cuts for motivational reasons (see (Bewley 1998) and (Howitt 2002)). The results are relatively similar when native and immigrant workers are analysed separately. In some years, nominal wage rigidity is higher for immigrants than for natives and the opposite happens in other years. On average, in the 2003-2008 period, the difference between natives and immigrants in terms of the incidence of nominal wage rigidity is small (around 1 percentage point).

The differences between natives and immigrants in terms of real wage rigidity are higher. For the total sample, 19.7 percent of the workers who would face a decline in their real wages in a context of wage flexibility, see their wages increase in line with the expected inflation rate in the period 2003-2008. The average percentage of immigrant workers affected by real wage rigidity in this period reaches 22.7 percent, which compares to 18.1 percent for native workers.

The real wage rigidity measures have an irregular behaviour over the 2003-2008 period. The estimated measures tend to increase from 2003 to 2006, are virtually nil in 2007 and increase again in 2008, but to a level below the average of previous years. The reduction in the real rigidity measures in the last two years was common to native and immigrant workers.

Up to 2006, the real wage rigidity measure combined both "strictly" real and institutional rigidities, related to collective bargaining and mandatory minimum wages. In the distribution of wage changes, the share of individuals covered by collective bargaining and/or earning the minimum wage reinforced the spike at the expected inflation rate. In contrast, in 2007 and 2008, instead of having a two-spike distribution of wage changes, 
the distribution of wage changes has three spikes - at zero, at the expected inflation rate (and wage bargaining reference value), and at the rate of change of the minimum wage. In these years, the IWFP methodology only takes into account the non-zero spike that is more significant in the range of the estimated expected inflation rate. Hence, in both years, the focal points implicit in the real rigidity measures do not reflected the rate of change of the minimum wage and the corresponding real rigidity measures do not include the percentage of minimum wage earners ${ }^{11}$. Hence, the evolution of the minimum wage induced a break in the series of the real wage rigidity measure in 2007.

In the period until 2006, we obtained higher values of the real rigidity measure for immigrants. Why would immigrants be more prone to real wage freezes? There are several factors that can contribute to this result like differences in terms of tenure, the incidence of the different types of contract, the sectoral distribution of workers or the proportion of minimum wage earners. In 2008, where the estimated real wage rigidity measure captures only "strictly" real rigidity and not the impact of mandatory minimum wages, the percentage of workers affected by real wage rigidity is smaller for immigrants than for natives. So, the higher real wage rigidity for immigrants up to 2006 is likely to reflect the higher concentration of immigrant workers in the minimum wage.

To better assess the impact of the minimum wage on the incidence of downward wage rigidity in Portugal, we re-estimated the rigidity measures using a sample that excludes all workers earning the minimum wage (Figure 5). The estimated measures of nominal wage rigidity are higher in the sample that excludes minimum wage earners, but the difference between natives and immigrants is similar. Since minimum wage earners are not subject to nominal wage rigidity, this increase in the measures has a simple statistical justification: the sample of workers is now smaller, but the workers affected by nominal wage rigidity are essentially the same, so the proportion of these workers increases.

The real wage rigidity measures estimated in the sample without minimum wage workers are smaller than the ones estimated in the full sample for both natives and immigrants. However, the exclusion of minimum wage earners from the sample leads to a sharper reduction of the proportion of immigrant workers subject to real wage rigidity (to 16.1 percent), which is now slightly below the one estimated for natives (17.6 percent). So, the higher real wage rigidity measure estimated for immigrants in the total

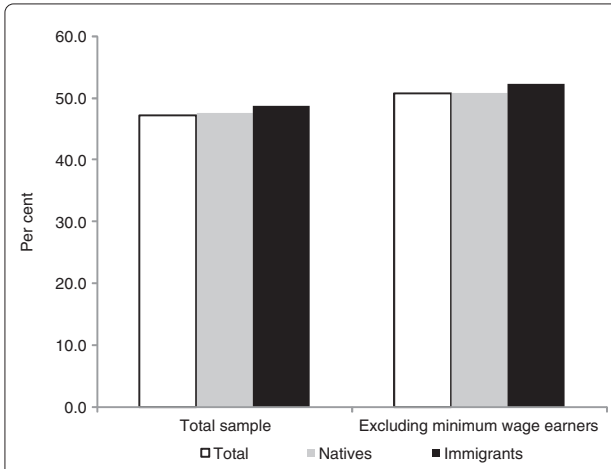

(a)

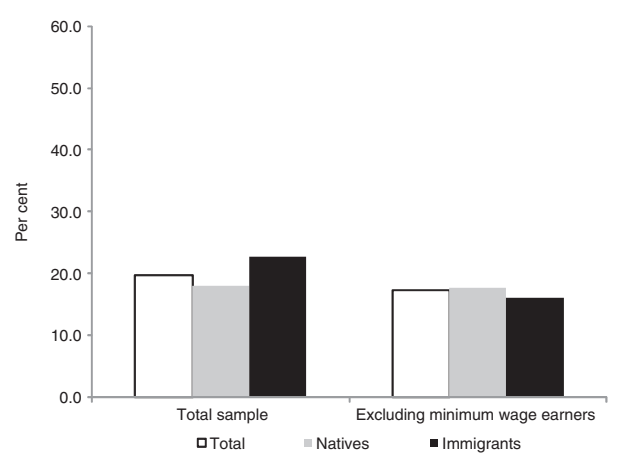

(b)

Figure 5 Nominal and real wage rigidity excluding minimum wage earners, average 2003-2008. (a) Downward nominal wage rigidity, (b) Downward real wage rigidity. 
sample appears to be linked to the higher share of minimum wage earners in immigrant employment.

As suggested in Figure 3, the mean of the estimated notional wage change distribution is always smaller than that of the empirical wage change distribution, reflecting the existence of wage rigidities. The related wage sweep-ups, which measure the overall increase in the average wage growth due to the presence of rigidities, are higher for immigrants than for natives, in particular due to non-nominal wage rigidity (Figure 6). Recall that, even if the real wage rigidity measures do not capture the effect of legal minimum wages in 2007 and 2008, the average wage sweep-ups always include, by construction, the impact of both real and institutional rigidities on average wages. In the absence of downward real and institutional wage rigidity, the average wages of immigrants would have grown by less 1.9 percentage points per year on average during this period, which compares to 1.2 percentage points for native workers. In comparison, the average wage sweep-up caused by nominal rigidity for immigrant workers is smaller (1.2 percentage points per year) and similar to the one obtained for natives (1.0 percentage points).

\subsection{Accounting for heterogeneity by immigrant origin}

The previous estimates differentiate between natives and immigrants but assume that wage rigidity is homogeneous among immigrants' nationalities. As described in Section 3.1, immigrant workers in Portugal are not a homogeneous group, so we reestimated the model using separate samples for the major immigrant groups in Portugal (Brazil, PALOP and CEEC) and also for the EU15 and China. Immigrants from the EU15 are very different from the average immigrant worker, as they are much more qualified and earn much higher wages, on average. At the other extreme are the immigrants from China, which grew strongly in recent years: they are the least qualified and earn the lowest wages, on average. Table 2 shows the estimated nominal and real wage rigidity measures for each immigrant group, on average in the 2003-2008 period.

The measure of nominal rigidity estimated for immigrants from PALOP is the lowest of all nationality groups considered, including the natives. This result is in line with most labour market theories that predict a lower wage rigidity for low-skilled blue-collar

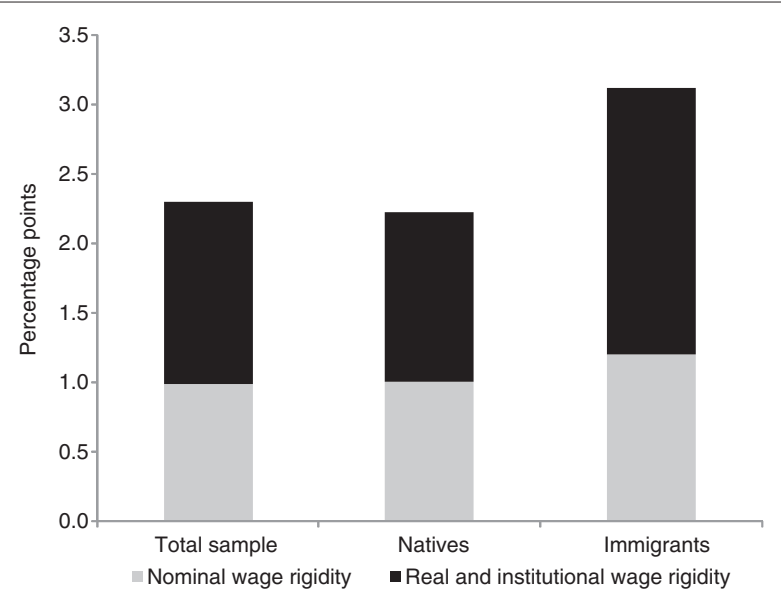

Figure 6 Average wage sweep-up due to downward wage rigidity, average 2003-2008. 
Table 2 Nominal and real wage rigidity by main nationalities, in percentage, average 2003-2008

\begin{tabular}{|c|c|c|c|c|c|c|c|c|}
\hline & Total & Natives & Immigrants & EU15 & PALOP & CEEC & Brazil & China \\
\hline \multicolumn{9}{|l|}{ Total sample } \\
\hline Nominal wage rigidity & 47.1 & 47.6 & 48.8 & 53.7 & 38.8 & 57.9 & 60.2 & 64.8 \\
\hline Real wage rigidity & 19.7 & 18.1 & 22.7 & 28.0 & 19.1 & 25.1 & 28.4 & 45.0 \\
\hline \multicolumn{9}{|l|}{$\begin{array}{l}\text { Excluding minimum } \\
\text { wage earners }\end{array}$} \\
\hline Nominal wage rigidity & 50.7 & 50.9 & 52.3 & 58.4 & 41.3 & 51.5 & 54.3 & 77.5 \\
\hline Real wage rigidity & 17.3 & 17.6 & 16.1 & 25.8 & 19.5 & 10.8 & 16.3 & 12.5 \\
\hline
\end{tabular}

workers. These workers have a lower probability of reducing effort or quitting the job in response to a wage cut. The cost of hiring and training replacements and the loss of firm-specific human capital if the workers quit are also less significant for these workers. In addition, more than 15 percent of immigrants from PALOP are employed in temporary work agencies and in cleaning services, typically jobs with low replacement costs and, hence, more prone to wage cuts. A symmetric reasoning for high-skilled white-collar workers applies to the high nominal rigidity obtained for EU15 immigrants. At odds with these theoretical predictions, the estimated measures of nominal wage rigidity of immigrants from CEEC, Brazil and China are above those of native workers. However, this result is in line with other studies that found that nominal wage rigidity tends to be high at the bottom of the earnings distribution (see (Du Caju et al. 2007) for Belgium).

The estimated measures of real wage rigidity of the different immigrant groups are above those of native workers, but the difference is very small in the case of PALOP workers. Chinese workers, which have the highest proportion of minimum wage earners, also have the highest value for the real wage rigidity measure. In fact, with the exception of EU15 and PALOP workers, the estimated higher real wage rigidity measure seems to reflect the greater concentration of immigrant workers in the minimum wage. Excluding minimum wage earners from the sample, we obtain a lower incidence of real wage rigidity for these immigrant groups than for native workers.

The combined average wage sweep-ups due to wage rigidity for the various immigrant groups are higher than those estimated for natives (Figure 7). This difference is higher in the case of EU15 and Chinese immigrants: the effect of sweeping up all nominal and real notional wage cuts for workers affected by wage rigidity raises average wage growth by around 3 percentage points per year in both cases. This increase in average labour costs due to downward wage rigidity can have an adverse impact in future labour market outcomes. (Barwell and Schweitzer 2007) found that British workers who are more likely to be protected from wage cuts are also more likely to lose their jobs and (Devicienti et al. 2007) concluded that downward wage rigidities in Italy have a positive impact on worker turnover at the firm level and on local unemployment rates. This fact can be especially important for immigrant groups with a higher share of young and poorly educated workers with fixed-term contracts. The higher educational level and incidence of permanent contracts of EU15 immigrants can shield them more as firms try to replace workers affected by downward rigidities in response to adverse demand shocks.

\section{Conclusions}

Some characteristics of immigrant workers, as the high share of fixed-term contracts and their higher geographical mobility, can lead to an increase in the flexibility of the labour 


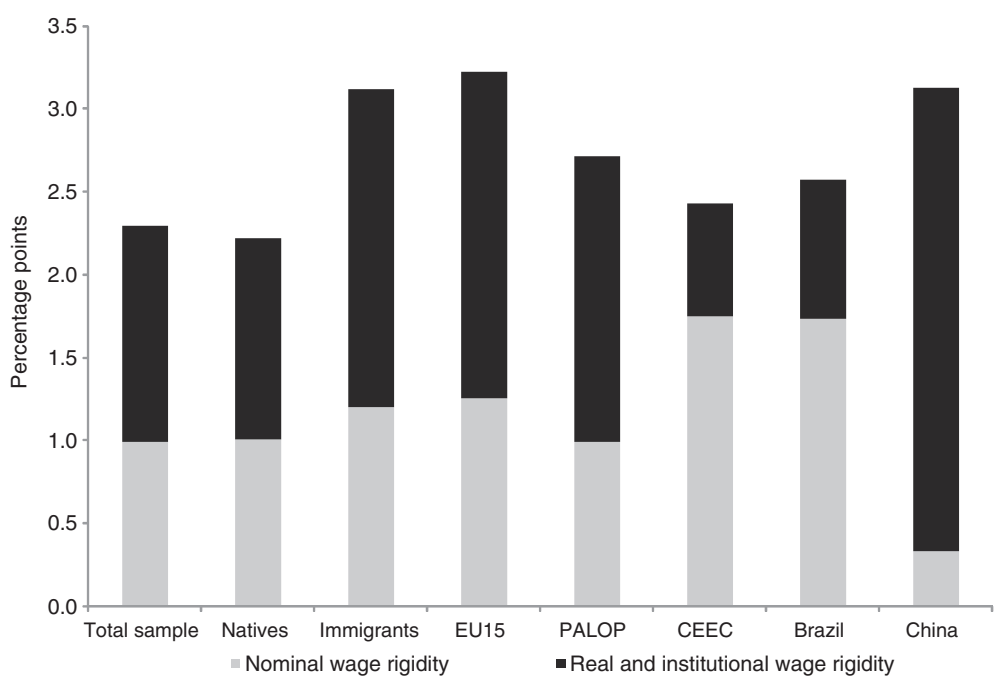

Figure 7 Average wage sweep-up due to downward wage rigidity by main nationalities, average 2003-2008.

market. But what about wages changes? In a low inflation environment, nominal wage rigidity can be an important obstacle to the real wage adjustments that firms need to do in response to negative demand shocks. This effect can be especially strong in a country like Portugal where there is specific legislation, like the illegality of cutting nominal base wages, that directly influences nominal wage rigidity. (Carneiro et al. 2013) find that downward wage rigidity in Portugal is associated with lower net job creation and higher failure rates of firms. According to most theories, one would expect a higher wage rigidity for natives, which are on average older, more-tenured, have greater bargaining power and a much higher share of permanent contracts. So, immigrant workers could help to increase wage flexibility, thus improving the allocative role of wages in the labour market.

In this paper, we investigate the differences in terms of downward nominal and real wage rigidity between natives and immigrants in Portugal, using micro data on individual wages from 2002 to 2008 and accounting for the potential heterogeneity of immigrants by main origins.

The answer to our initial question is no, nationality does not seem to matter that much, but if anything immigrants' wages tend to be more rigid. The average wage sweep-ups, which measure the overall increase in the average wage growth due to the presence of rigidities, are higher for immigrants than for natives, in particular due to non-nominal wage rigidity. Therefore, a higher percentage of immigrant workers in the Portuguese labour market does not seem to result in higher wage flexibility, contradicting our initial expectations.

What can explain this evidence? The institutional characteristics of the Portuguese labour market - mandatory minimum wages and collective wage agreements - play a crucial role in the wage-setting procedure and are common to native and immigrant workers. The higher measure of real wage rigidity obtained for immigrants is associated with a higher incidence of institutional rigidity, given the greater share of immigrants receiving the minimum wage. Excluding minimum wage earners from the sample, the 
estimated measures of real wage rigidity are slightly smaller for immigrants than for natives.

We also assess the extent of nominal and real wage rigidity by main immigrant nationalities and find that the results are not homogeneous across different immigrant groups. The incidence of nominal wage rigidity among workers from Portuguese speaking countries in Africa (PALOP) is the lowest of all nationality groups considered, including the natives. This result is in line with most labour market theories that predict a lower wage rigidity for low-skilled blue-collar workers. The proportion of workers affected by downward real wage rigidity is the highest for immigrants from China, reflecting the greater concentration of these workers in the minimum wage. Excluding minimum wage earners from the sample, we obtain a lower incidence of real wage rigidity for Chinese immigrants than for natives.

We consider that the evidence in this paper uncovers an interesting link between the literature on wage differences between natives and immigrants and the ongoing debate about the setting of minimum wages and their policy implications. (Centeno et al. 2011) estimate the impact of increases in the minimum wage on employment stability, wages and inequality in Portugal and find evidence of a detrimental effect of minimum wage increases for employment stability of low-wage workers, with only minor gains in terms of wages. In addition, our evidence suggests that the minimum wage contributes to increase wage rigidity, in general, and even further in the case of immigrants, with potential negative effects on the employment prospects of immigrant workers.

\section{Endnotes}

${ }^{1}$ By law, workers formally classified as apprentices can receive a minimum wage that is, at least, 80 percent of the full rate.

${ }^{2}$ The distributions of nominal wages are similar throughout the period analysed. All annual distributions are available from the authors upon request.

${ }^{3}$ We consider as minimum wage earners all workers whose nominal wage lies in the interval of 1 euro centred on the minimum wage.

${ }^{4}$ The nominal minimum wage amounted to 348 in 2002, 356.6 in 2003, 365.6 in 2004, 374.7 in 2005, 385.9 in 2006, 403 in 2007 and 426 in 2008 (values in euros).

${ }^{5}$ For the several test performed to generate the notional or counterfactual wage change distribution and the justification of the choice of the Weibull distribution, see (Dickens and Goette 2005).

${ }^{6}$ The same reasoning applies when we go into further detail to assess the impact of the minimum wage or the heterogeneity of the results by main immigrant nationalities: all estimations were replicated using the respective separate samples (e.g. natives not earning the minimum wage, immigrants from Brazil, etc.).

${ }^{7}$ The results are qualitatively invariant to a different choice of threshold for selecting the random sample.

${ }^{8}$ All distributions are available from the authors upon request.

${ }^{9}$ All results are available from the authors upon request.

${ }^{10}$ The corresponding distributions estimated for the separate samples of natives and immigrants are omitted for the sake of brevity. Again, all distributions are available from the authors upon request.

${ }^{11}$ By restricting the range over which the IWFP routine searches for signs of real wage rigidity one could force the results to reflect the rate of change of the minimum wage spike. We opted against imposing an ad-hoc range based on a judgment, letting the routine freely select the most significant non-zero spike. 


\section{Appendix}

This Appendix includes two tables. For the sample of job stayers, Table 3 shows the sample means of some relevant variables for natives, immigrants, and the five main nationalities of immigrant workers. Table 4 reports the main results of the estimation of downward nominal and real wage rigidity using International Wage Flexibility Project (IWFP) methodology for natives and immigrants. It includes the yearly estimates of the notional and empirical average wage changes, the corresponding average wage sweepups, the expected inflation rate, the nominal and real rigidity measures for the whole sample and for natives and immigrants, as well as the respective sample sizes.

Table 3 Main characteristics of native and immigrant workers in Portugal, sample of job stayers, average 2002-2008

\begin{tabular}{|c|c|c|c|c|c|c|c|}
\hline & Natives & Immigrants & EU15 & PALOP & CEEC & Brazil & China \\
\hline Levels in 2008 & $1,386,734$ & 62,374 & 7,241 & 15,208 & 14,901 & 13,454 & 804 \\
\hline Share in total, 2008 & 95.7 & 4.3 & 11.6 & 24.4 & 23.9 & 21.6 & 1.3 \\
\hline \multicolumn{8}{|l|}{ Type of contract (\%) } \\
\hline Permanent contract & 81.6 & 53.2 & 72.2 & 59.6 & 40.0 & 43.3 & 48.3 \\
\hline Fixed-term contract & 18.4 & 46.8 & 27.8 & 40.4 & 60.0 & 56.7 & 51.7 \\
\hline \multicolumn{8}{|l|}{ Age } \\
\hline Average years & 38.1 & 36.1 & 36.9 & 37.0 & 36.5 & 33.4 & 34.4 \\
\hline$\%$ workers aged less 35 years & 42.4 & 48.9 & 49.3 & 43.9 & 46.5 & 60.9 & 53.3 \\
\hline \multicolumn{8}{|l|}{ Tenure } \\
\hline Average years & 8.1 & 3.3 & 4.6 & 3.8 & 2.2 & 2.1 & 1.8 \\
\hline$[0,3]$ & 39.2 & 71.3 & 56.7 & 65.0 & 81.9 & 82.6 & 86.2 \\
\hline \multicolumn{8}{|l|}{ Educational attainment (\%) } \\
\hline Illiterate & 1.2 & 4.2 & 0.5 & 5.4 & 6.8 & 1.7 & 17.1 \\
\hline 4 years completed & 24.0 & 21.8 & 7.2 & 31.7 & 20.6 & 16.4 & 41.3 \\
\hline 6 years completed & 22.0 & 17.1 & 11.7 & 16.9 & 17.0 & 18.9 & 13.9 \\
\hline 9 years completed & 20.9 & 23.4 & 18.8 & 21.4 & 26.4 & 26.2 & 18.5 \\
\hline 12 years completed & 20.2 & 23.1 & 28.8 & 17.2 & 22.9 & 29.8 & 6.4 \\
\hline Tertiary & 11.6 & 10.4 & 33.0 & 7.4 & 6.3 & 7.0 & 2.8 \\
\hline \multicolumn{8}{|l|}{ Main sectors of activity (\%) } \\
\hline Manufacturing industry & 30.1 & 19.3 & 22.3 & 11.2 & 26.2 & 13.4 & 1.3 \\
\hline Construction & 10.7 & 20.9 & 7.6 & 26.3 & 29.3 & 16.8 & 0.6 \\
\hline Services, of which: & 56.5 & 56.5 & 67.7 & 61.3 & 37.9 & 67.8 & 98.0 \\
\hline Wholesale and retail trade & 20.2 & 15.3 & 20.3 & 13.1 & 10.1 & 18.2 & 53.9 \\
\hline Hotels and restaurants & 5.7 & 14.8 & 9.8 & 15.4 & 10.4 & 23.3 & 41.7 \\
\hline Business services & 8.6 & 10.9 & 11.8 & 16.7 & 6.7 & 11.0 & 0.9 \\
\hline Other sectors & 2.7 & 3.3 & 2.4 & 1.2 & 6.6 & 1.9 & 0.1 \\
\hline \multicolumn{8}{|c|}{ Average nominal monthly wage } \\
\hline In Euros & 858.3 & 790.6 & 1507.9 & 718.8 & 599.3 & 787.8 & 456.8 \\
\hline \% Minimum wage earners & 7.3 & 11.7 & 6.1 & 7.8 & 13.5 & 14.9 & 56.3 \\
\hline
\end{tabular}

Source: Quadros de Pessoal.

Notes: The sample of job stayers includes only the workers who stayed for at least two consecutive years in the same firm. The shares of main immigrant groups are computed as a percentage of total immigrants. EU15 includes the other 14 initial

Member-States of European Union. CEEC (Central and Eastern European countries) includes Slovakia, Poland, Czech Republic, Hungary, Estonia, Slovenia, Latvia, Lithuania, Romania, Russian Federation, Moldova, Ukraine and Serbia. PALOP (Países Africanos de Língua Oficial Portuguesa) refers to the former Portuguese colonies in Africa (Angola, Cape Verde, Guinea Bissau, Mozambique, and São Tomé and Príncipe). Illiterate refers to no formal education or below ISCED 1, 4 years completed (primary education) and 6 years completed (second stage of basic education) are both included in ISCED 1, 9 years completed refers to ISCED 2 (lower secondary education), 12 years completed refers to ISCED 3-4 (upper-secondary) and tertiary refers to ISCED 5-6. ISCED stands for International Standard Classification of Education. The percentage of minimum wage earners was computed considering workers with wages in the interval of $+/-1$ euro centred on the minimum wage. 


\begin{tabular}{|c|c|c|c|c|c|c|c|}
\hline Total sample & 2003 & 2004 & 2005 & 2006 & 2007 & 2008 & 2003-2008 \\
\hline Average empirical wage change & 4.3 & 4.2 & 4.3 & 4.1 & 4.6 & 4.9 & 4.4 \\
\hline Average notional wage change & 2.3 & 1.7 & 2.0 & 1.5 & 2.6 & 2.6 & 2.1 \\
\hline Expected inflation rate & 2.8 & 2.7 & 2.5 & 2.4 & 2.4 & 2.3 & 2.5 \\
\hline Average wage sweep-up, from: & 2.0 & 2.5 & 2.2 & 2.6 & 2.1 & 2.3 & 2.3 \\
\hline Nominal wage rigidity & 1.1 & 0.9 & 1.1 & 1.1 & 1.0 & 0.9 & 1.0 \\
\hline Real and institutional wage rigidity & 1.0 & 1.6 & 1.2 & 1.5 & 1.1 & 1.4 & 1.3 \\
\hline Nominal wage rigidity measure & 45.8 & 42.7 & 48.6 & 50.6 & 48.0 & 47.1 & 47.1 \\
\hline Real wage rigidity measure & 16.9 & 28.5 & 22.4 & 30.8 & 0.0 & 19.5 & 19.7 \\
\hline Number of observations & 171,270 & 169,835 & 173,582 & 173,903 & 173,408 & 144,911 & - \\
\hline Natives & 2003 & 2004 & 2005 & 2006 & 2007 & 2008 & 2003-2008 \\
\hline Average empirical wage change & 4.3 & 4.2 & 4.3 & 4.1 & 4.6 & 4.9 & 4.4 \\
\hline Average notional wage change & 2.3 & 2.0 & 2.0 & 1.5 & 2.5 & 2.6 & 2.2 \\
\hline Expected inflation rate & 2.9 & 2.8 & 2.5 & 2.4 & 2.4 & 2.3 & 2.5 \\
\hline Average wage sweep-up, from: & 2.0 & 2.2 & 2.2 & 2.6 & 2.1 & 2.3 & 2.2 \\
\hline Nominal wage rigidity & 1.1 & 1.0 & 1.0 & 1.1 & 1.0 & 0.9 & 1.0 \\
\hline Real and institutional wage rigidity & 1.0 & 1.2 & 1.2 & 1.5 & 1.1 & 1.4 & 1.2 \\
\hline Nominal wage rigidity measure & 46.0 & 45.6 & 48.2 & 50.4 & 48.3 & 47.2 & 47.6 \\
\hline Real wage rigidity measure & 15.8 & 19.6 & 22.4 & 30.5 & 0.2 & 19.9 & 18.1 \\
\hline Number of observations & 163,597 & 161,802 & 165,205 & 165,593 & 165,157 & 138,673 & - \\
\hline Immigrants & 2003 & 2004 & 2005 & 2006 & 2007 & 2008 & 2003-2008 \\
\hline Average empirical wage change & 4.5 & 4.3 & 4.7 & 4.6 & 5.3 & 5.5 & 4.8 \\
\hline Average notional wage change & 1.7 & -0.1 & 1.9 & 1.1 & 2.7 & 2.8 & 1.7 \\
\hline Expected inflation rate & 2.8 & 2.5 & 2.5 & 2.4 & 2.4 & 2.3 & 2.5 \\
\hline Average wage sweep-up, from: & 2.8 & 4.3 & 2.8 & 3.5 & 2.6 & 2.7 & 3.1 \\
\hline Nominal wage rigidity & 1.1 & 1.5 & 1.2 & 1.4 & 1.0 & 0.9 & 1.2 \\
\hline Real and institutional wage rigidity & 1.8 & 2.8 & 1.6 & 2.1 & 1.6 & 1.7 & 1.9 \\
\hline Nominal wage rigidity measure & 43.3 & 53.9 & 49.1 & 54.9 & 47.6 & 43.8 & 48.8 \\
\hline Real wage rigidity measure & 31.9 & 34.9 & 25.2 & 31.2 & 0.4 & 13.0 & 22.7 \\
\hline Number of observations & 76,727 & 80,329 & 83,769 & 83,102 & 82,510 & 62,374 & - \\
\hline
\end{tabular}

Notes: All samples include only workers who stayed for at least two consecutive years in the same firm (job stayers). In the case of the total and natives samples, the number of observations in each year refers to a 10 percent random sample that was selected from the respective samples of job stayers for estimating the rigidity measures. In the case of immigrants, the number observations refers to the total sample of job stayers.

\section{Competing interests}

The IZA Journal of European Labor Studies is committed to the IZA Guiding Principles of Research Integrity. The authors declare that they have observed these principles.

\section{Acknowledgements}

The authors thank an anonymous referee for helpful comments and suggestions. The usual disclaimers apply. Responsible editor: Sara De la Rica.

Received: 3 December 2013 Accepted: 14 February 2014

Published: 2 July 2014

\section{References}

Akerlof GA, Dickens WR, Perry GL (1996) The macroeconomics of low inflation. Brookings Papers on Economic Activity 27(1996-1): 1-76

Altonji JG, Devereux PJ (2000) The extent and consequences of downward nominal wage rigidity. Res Labor Econ 19: 383-431

Aydemir A, Skuterud M (2005) Explaining the deteriorating entry earnings of Canada's immigrant cohorts, 1966-2000. Can J Econ 38(2): 641-672

Barwell RD, Schweitzer ME (2007) The incidence of nominal and real wage rigidities in Great Britain: 1978-98. Econ J 117(524): F553-F569

Bewley TF (1998) Why not cut pay?', Eur Econ Rev 42(3-5): 459-490 
Blanchard O, Galí J (2007) Real wage rigidities and the new Keynesian model. J Money Credit Bank 39(s1): 35-65 Borjas GJ (1999) The economic analysis of immigration. In: Ashenfelter O, Card D (eds) Handbook of Labor Economics, Vol. 3,. Elsevier, USA, chapter 28, pp. 1697-1760

Borjas GJ (2003) The labor demand curve is downward sloping: Reexamining the impact of immigration on the labor market. Q J Econ 118(4): 1335-1374

Cabral S, Duarte C (2013) Mind the gap! The relative wages of immigrants in the Portuguese labour market. Working Paper 05-2013, Banco de Portugal, Lisboa, Portugal

Campbell CM, Kamlani KS (1997) The reasons for wage rigidity: Evidence from a survey of firms. Q J Econ 112(3): 759-89

Card D, Hyslop D (1997) Does inflation "grease the wheels of the labor market"? In: Romer CD, Romer DH (eds) 'Reducing Inflation: Motivation and Strategy'. National Bureau of Economic Research, Cambridge, Massachusetts, chapter 2, pp 71-122

Cardoso AR, Portugal P (2005) Contractual wages and the wage cushion under different bargaining settings. J Labor Econ 23(4): $875-874$

Carneiro A, Guimarães P, Portugal P (2012) Real wages and the business cycle: Accounting for worker, firm, and job title heterogeneity. Am Econ J Macroecon 4(2): 133-152

Carneiro A, Portugal P, Varejão J (2013) Catastrophic job destruction during the Portuguese economic crisis. J Macroecon Available online 8 October 2013, ISSN 0164-0704. [http://dx.doi.org/10.1016/j.jmacro.2013.09.018]

Centeno M, Duarte C, Novo AA (2011) The impact of the minimum wage on low-wage earners. Banco de Port Econ Bul Autumn: 107-121

Devicienti F, Maida A, Sestito P (2007) Downward wage rigidity in Italy: Micro-based measures and implications. Econ J 117(524): F530-F552

Dickens W, Goette L (2005) Estimating wage rigidity for the international wage flexibility project, mimeo. The Brookings Institution, Washington DC, USA. [http://www.brookings.edu/es/research/projects/200509_iwfp.pdf]

Dickens W, Goette L, Groshen E, Holden S, Messina J, Schweitzer M, Turunen J, Ward M (2007) How wages change: Micro evidence from the international wage flexibility project. J Econ Perspect 21(2): 195-214

Du Caju P, Fuss C, Wintr L (2007) Downward wage rigidity for different workers and firms: An evaluation for Belgium using the IWFP procedure. Working Paper Series 840, European Central Bank, Frankfurt am Main, Germany

Duarte C (2008) A sectoral perspective on nominal and real wage rigidity in Portugal. Banco de Port Econ Bull Autumn: 187-199

Dustmann C, Glitz A, Vogel T (2010) Employment, wages, and the economic cycle Differences between immigrants and natives. Eur Econ Rev 54(1): 1-17

Friedberg RM (2000) You can't take it with you? Immigrant assimilation and the portability of human capital. J Labor Econ 18(2): 221-251

Goette L, Sunde U, Bauer T (2007) Wage rigidity: Measurement, causes and consequences. Econ J 117(524): F499-F507

Howitt P (2002) Looking inside the labor market: A review article. J Econ Lit 40(1): 125-138

Kahn S (1997) Evidence of nominal wage stickiness from microdata. Am Econ Rev 87(5): 993-1008

Lindbeck A, Snower D (1988) The Insider-Outsider Theory of Employment and Unemployment. The MIT Press, Cambridge, Massachusetts

Messina J, Duarte CF, Izquierdo M, Caju PD, Hansen NL (2010) The incidence of nominal and real wage rigidity: An individual-based sectoral approach. J Eur Econ Assoc 8(2-3): 487-496

Ottaviano Gl, Peri G (2012) Rethinking the effect of immigration on wages. J Eur Econ Assoc 10(1): 152-197

Taylor JB (1979) Staggered wage setting in a macro model. Am Econ Rev 69(2): 108-113

doi:10.1186/2193-9012-3-13

Cite this article as: Cabral and Duarte: Nominal and real wage rigidity: Does nationality matter? IZA Journal of European Labor Studies 2014 3:13.

\section{Submit your manuscript to a SpringerOpen ${ }^{\circ}$ journal and benefit from:}

- Convenient online submission

- Rigorous peer review

- Immediate publication on acceptance

- Open access: articles freely available online

- High visibility within the field

- Retaining the copyright to your article

Submit your next manuscript at $\boldsymbol{\wedge}$ springeropen.com 